\title{
Epidemiology and family characteristics of severely-abused children
}

\author{
J. A. BALDWIN AND J. E. OLIVER \\ Unit of Clinical Epidemiology, University of Oxford
}

\begin{abstract}
Baldwin, J. A. and Oliver, J. E. (1975). British Journal of Preventive and Social Medicine, 29, 205-221. Epidemiology and family characteristics of severely-abused children. Severe child abuse in north-east Wiltshire was studied retrospectively during the period 1965-71, and prospectively for 18 months from January 1972, after a period of consultative activity with those actively involved to increase awareness of the phenomenon. Severe abuse was strictly defined. A rate of 1 per thousand children under four years old was obtained, together with a death rate of 0.1 per thousand. The families of the retrospective series of abused children were studied in detail, and identifying characteristics of large family size, youthfulness, low social-class, instability, and gross psychiatric, medical, and social pathology described. The implications of the ascertainment and death rates are discussed in relation to data from some other studies, and the need emphasized for detailed studies of the apparent clustering of disorder in the families, using linked record systems.
\end{abstract}

In contrast to the situation a few years ago, when child abuse was relatively rarely recognized or openly diagnosed, there have been several reports recently suggesting that the incidence is high. Castle and Kerr (1972) found 292 cases of children under four years old in England and Wales in 1970, a rate of about $0 \cdot 1 / 1000$. The Tunbridge Wells study group (Franklin, 1973) estimated that there were 4600 cases a year in the United Kingdom, including 700 deaths and 400 children brain damaged. Light (1973), using all available USA data, suggested that $4 / 1000$ families with children under 18 years old physically abused at least one of their children and estimated that about 200000 children were involved. He considered that $1 \%$ of American children under 18 years were physically abused, severely neglected, or subjected to sexual abuse.

If child abuse is a public health problem of this magnitude it demands serious and urgent action to ascertain and treat cases, to pursue secondary prevention, and to promote programmes for primary prevention. Reports, such as those cited, and publicity resulting from recent cases have brought about much greater awareness among the medical and social service professions with consequent increases in numbers of cases reported. Even so, some authorities believe there is an increase in incidence (Ounsted, 1975). Clearly priority must be given to estimating incidence and identifying persons and families at high risk. A major difficulty with currently available information is the lack of clarity of definition and consequent uncertain meaning of the figures.

This paper reports a study in north-east Wiltshire begun in 1971 to ascertain the extent of severe abuse in young children in a geographically defined population and to describe salient features of their families. North-east Wiltshire has a population of 200000 with about 18500 children under five years old and 3600 live births annually. About $40 \%$ of the population is urban.

Part of the data was obtained retrospectively from reports of cases in whom severe abuse first occurred in the period 1965-71. These cases and their families were studied in depth. In 1971 a programme of intensive discussion with professionals in the area was undertaken to improve case recognition. After this period, case reports were gathered prospectively during the 18-month period January 1972 to June 1973 for comparison, but they were not studied in detail. Because of the difficulties in case ascertainment and definition, the study was limited to families in which the presenting child was aged under five years, and had been subjected to very severe active physical abuse meeting defined criteria. 


\section{Material AND Method}

\section{Criteria for Severe Abuse}

Satisfaction of any one or more of the following six criteria merited inclusion of the family of a child under five years old:

1. Prolonged assaults of such severity that death ensued (Cameron, Johnson, and Camps, 1966; Scott, 1973a; Trube-Becker, 1971; Weston, 1968). Infanticides or murders were not included automatically (Lukianowicz, 1971; Rodenberg, 1971; Scott, 1973b).

2. Skull or facial bone fractures (O'Neill et al., 1973).

3. Bleeding into or around the brain (Birrell and Birrell, 1968; Guthkelch, 1971; Köttgen, 1967; Neimann and Rabouille, 1969; O'Neill et al., 1973; Straus and Wolf, 1970); brain damage with consequent impairment of either intellect or functioning of one of the senses or proper functioning of the central nervous system; direct damage to vision (Harcourt and Hopkins, 1971; Mushin, 1971).

4. Two or more instances of mutilation requiring medical attention such as bites (Cameron, 1972; Sims, Grant, and Cameron, 1973), burns, crushes, or cuts.

5. Three or more separate instances of fracture, and/or severe bruising requiring medical attention (Caffey, 1972; Cameron, 1970, 1972; Cameron et al., 1966; Ebbin et al., 1969; Grantmyre, 1973; Griffiths and Moynihan, 1963; Maroteaux and Fessard, 1969; Reeb et al., 1972; Silverman, 1968).

6. Multiple fractures and/or severe internal injuries (Birrell and Birrell, 1968; Cameron, 1970, 1972; Cameron et al., 1966; Silverman, 1968).

We were not able to consider as a criterion for severe abuse temporary impairment of oxygenation of the brain caused by assault. Reports of unconsciousness resulting from the intentional placing of polythene bags over the child's head, obstruction of breathing (including one instance of holding the child's head so that vomit was inhaled), obstruction of neck vessels, and holding the child's head under water were frequent events in certain families.

Moderate Abuse Degrees of assault or injury which approached but did not entirely meet the criteria for severe abuse were classified as 'moderate abuse', and episodes of suffocation were included. Siblings of severely-abused children frequently met the criteria for moderate abuse and data on them are presented briefly. Families were referred with children who could be placed only in the 'moderate abuse' category but these were under- $\mathbb{D}$ estimated and data on them are not presented in this paper.

NeGLeCT Many of the presenting children and their siblings had undergone other forms of ill- $\frac{\bar{c}}{\frac{\bar{s}}{}}$ treatment in addition to the essential criteria for $\mathbb{Q}$ selection. These included deprivation of food, fluids, freedom, warmth, medical treatment, etc. s (Elmer, 1960; Leonard, Rhymes, and Solnitt, 1966; Maginnis, Pivchik, and Smith, 1967; Smith and $\vec{\omega}$ Hanson, 1972; Young, 1964), prolonged unnecessary psychological stress, and various mental assaults (Cherry and Kuby, 1971; Clegg and Megson, $\stackrel{\Upsilon}{+}$ 1968; Pavenstedt and Bernard, 1971). This group of ill-treatments was classified as 'neglect' and further subdivided into 'severe' and 'moderate' $O$ according to the severity and duration of the deprivation, and the age of the child. Abandonment was classified as a form of neglect.

\section{CRITERIA for INCLUSION IN STUdy}

If a child was ascertained as having been injuree in such a way as to satisfy one or more of the criteria for severe abuse, the family was include $\vec{\theta}$ in the study if the severe abuse occurred when the or child was under five years old and in the period January 1965 to June 1973, and while the family was resident in north-east Wiltshire.

Certain of the brothers and sisters had been assaulted in similar or more severe ways than the presenting children. These sibs were not counted as index children if the injuries were not inflicted during the relevant period, if the child was over five years old at the time of the injury, or if the family was not in the demarcated area of north-east Wiltshire at that time.

ASCERTAINMENT OF THE Numbers OF YOUNG Children Fulfilling the 'Severe Abuse' Criteria, and Selection of Families for INTENSIVE Study

One of us (JEO) was in an almost unique situation in which to obtain access to confidential data. His responsibilities encompassed most of the depart $-\frac{D}{0}$ ments directly or indirectly concerned with child welfare in the area. The study team personally $N^{N}$ saw most of the officials and professional people concerned with the health and welfare of young children in north-east Wiltshire, explained the ${ }^{\omega}$ criteria and listened to comments, reservations, and other points of issue. The individuals and agencies which identified severely and actively ill-treated 
young children over the period January 1965 to June 1973 are shown in Table I. The total number of such children was 60 .

\section{TABLE I}

SEVERELY-ABUSED YOUNG CHILDREN IN NORTH-EAST WILTSHIR 1965-73 NUMBERS OF NOTIFICATIONS * AND CONFIRMATIONS BY AGENCIES AND PROFESSIONAL OR OTHER GROUPS OF INDIVIDUALS

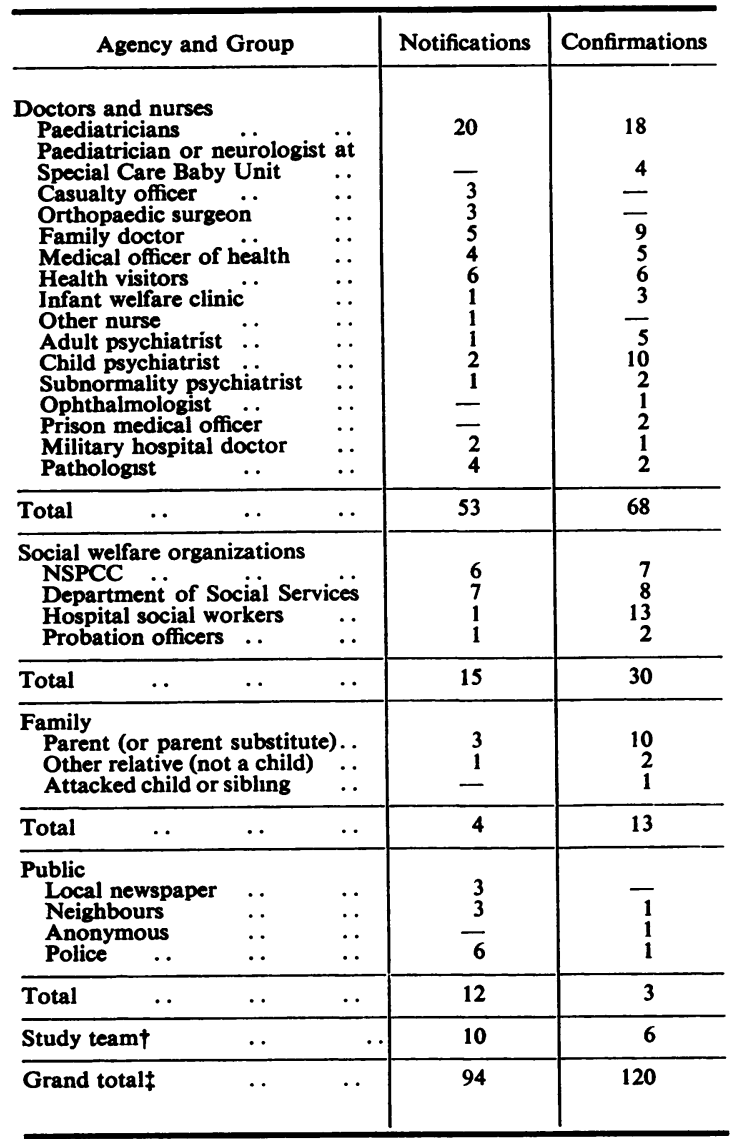

- Notification here means either that the professional or agency informed us, or that the Wiltshire Medical Officer of Health was informed, or that the diagnosis of 'baby battering' was claimed in newspaper articles.

t Information obtained by us while following up other children in the family suspected of having been ill-treated

¥ The totals are greater than the number of severely-abused young children (60) because notifications and confirmations could come from more than one source.

Nomadic and certain army families posed special problems. Families on the Tidworth Military and Lyneham RAF camps were excluded unless their children were referred to local services. We investigated as far as possible other families in the area whose children were assaulted in north-east Wiltshire but taken elsewhere for treatment, and a few nomads on the fringe of the area whose children were treated in our hospitals. Families of abused or neglected children from other parts of the Oxford RHB who were in subnormality hospitals in northeast Wiltshire were not investigated.

INVESTIGATION IN DePTH OF THE Retrospective SERIES OF 38 YOUNG CHILDREN FROM 34 FAMILIES Who had beEn Severely Abused IN the Seven YEARS 1965-71

For four of out the 34 families the information was gleaned entirely from other professional people and written notes. For the other 30 the information was both first hand and from professional people, and from files. The sources of information and methods of substantiating data have been discussed elsewhere (Oliver, 1970; Oliver and Cox, 1973; Oliver and Taylor, 1971; Oliver et al., 1974).

Obtaining reliable and relatively complete data on the $\mathbf{3 4}$ families was a complex task making heavy demands on time, energy, and imagination. Information was kept in coded confidential files to which we alone had access. Nevertheless, considerations of confidentiality often limited availability of data.

Parents also misrepresented themselves without necessarily consciously lying, omitting information, or deceiving. They frequently presented an ideal or facade which bore little relation to reality. Sentimentality could conceal irresponsibility in essentials. Sentimental or idealized versions of the parents' own upbringing often had led professional people to record accounts of neutral or innocuous family histories that were misleading. Parents commonly made global statements that indicated a belief in the normality of their own upbringing in general terms which contrasted dramatically with contradictory and unpleasant specific accounts couched in detailed terms. Such parents usually appeared unaware of these discrepancies, and became bewildered when their previous statements were compared. In this respect old records sometimes proved more reliable than direct interviews.

\section{RESULTS}

Altogether 38 children were ascertained as having been assaulted in the seven years 1965-71 in northeast Wiltshire to such an extent as to meet the criteria for severe abuse. These presenting children came from 34 families, four families each contributing two children, and these families were the subjects for detailed study. A further 22 children were ascertained as meeting the same criteria in the 18 months January 1972 to June 1973, but detailed data on them and their families are not presented. 
TABLE II

SEVERELY-ABUSED CHILDREN IN NORTH-EAST WILTSHIRE, 1965 - MID-1973. DISTRIBUTION BY SEX AND AGE AT START OF ABUSE

\begin{tabular}{|c|c|c|c|c|c|c|c|c|c|c|c|c|c|c|c|}
\hline \multirow{2}{*}{\multicolumn{4}{|c|}{ Age (in completed years) }} & \multicolumn{4}{|c|}{ Boys } & \multicolumn{4}{|c|}{ Girls } & \multicolumn{4}{|c|}{ Total } \\
\hline & & & & \multicolumn{2}{|c|}{$1965-71$} & \multicolumn{2}{|c|}{1972 - mid-73 } & \multicolumn{2}{|c|}{$1965-71$} & \multicolumn{2}{|c|}{1972 - mid-73 } & \multicolumn{2}{|c|}{$1965-71$} & \multicolumn{2}{|c|}{1972 - mid-73 } \\
\hline 0 & .. & .. & .. & 16 & $(72 \cdot 7)$ & 3 & $(37 \cdot 5)$ & 15 & $(93 \cdot 7)$ & 6 & $(42 \cdot 8)$ & 31 & $(81 \cdot 6)$ & 9 & $(40 \cdot 9)$ \\
\hline 1 & .. & . & .. & $\mathbf{0}$ & & 2 & $(25 \cdot 0)$ & 0 & & 6 & $(42 \cdot 8)$ & 0 & & 8 & $(36 \cdot 4)$ \\
\hline 2 & .. & . & . & 4 & $(18 \cdot 2)$ & 2 & $(25 \cdot 0)$ & 1 & $(6 \cdot 3)$ & 2 & $(14 \cdot 3)$ & 5 & $(13 \cdot 2)$ & 4 & $(18 \cdot 2)$ \\
\hline 3 & . & .. & . & 2 & $(9 \cdot 1)$ & 0 & & 0 & & 0 & & 2 & $(5 \cdot 2)$ & 0 & \\
\hline 4 & .. & .. & .. & 0 & & 1 & $(12 \cdot 5)$ & 0 & & 0 & & 0 & & 1 & $(4 \cdot 5)$ \\
\hline Total & . & .. & .. & 22 & $(100 \cdot 0)$ & 8 & $(100 \cdot 0)$ & 16 & $(100 \cdot 0)$ & 14 & $(99 \cdot 9)$ & 38 & $(100 \cdot 0)$ & 22 & $(100 \cdot 0)$ \\
\hline
\end{tabular}

\section{Presenting Children}

The sex and age distributions of children in the two series are shown in Table II. In the retrospective series four-fifths of them were under one year old at the onset of severe abuse and none was in the second year, while in the prospective series about the same proportion was fairly evenly divided between the first and second years of life. It was thought that in the earlier period one-year-old children, having passed from the responsibility of the paediatric services, were not under such close surveillance until they reached pre-school age. This suggestion is supported by the annual sex/age specific rates per thousand population (Table III). Of children under one year $83 \%$ of the retrospective series and $89 \%$ of the prospective series were under six months. Very few children were ascertained over the age of two years in either series. A possible explanation of the small numbers of three and four year olds is that by this age they are more robust and so less easily damaged to such an extent as meeting the criteria for severe abuse. Either their injuries are less severe because they are stronger or they are more successful in avoiding the most serious assaults. Less severely injured children i⿱⺈ this age group were ascertained. Furthermore proof that injury is not accidental is more difficulg Fractures, for example, may occur during play and it may be impossible to determine the precise cause

Boys outnumbered girls in the retrospectis series in the ratio $1.4: 1$. In contrast, boys were ov fewer than girls in the prospective series in the ratio $1: 1 \cdot 7$.

RATe of Severe Abuse The single case aged four years has been omitted from rate calculations $\stackrel{D}{\square}$ so that, unless otherwise specified, total rates are $\overrightarrow{\vec{O}}$ for the age group of up to three years. Table III 3 shows that the annual rate for children under four years in the prospective series was 2.6 times that in the retrospective series-almost 1 per thousand.

TABLE III

SEVERELY-ABUSED CHILDREN IN NORTH-EAST WILTSHIRE, 1965 - MID-1973. ANNUAL SEX AND AGE SPECIFIC RATES PER THOUSAND POPULATION

\begin{tabular}{|c|c|c|c|c|c|c|c|c|c|}
\hline & & & & \multicolumn{2}{|c|}{ Boys } & \multicolumn{2}{|c|}{ Girls } & \multicolumn{2}{|c|}{ Total } \\
\hline \multicolumn{4}{|c|}{ Age (in completed years) } & $1965-71$ & 1972 - mid-73 & $1965-71$ & 1972 - mid-73 & $1965-71$ & 1972 - mid-73 \\
\hline 0 & .. & .. & .. & $1 \cdot 22$ & 1.07 & $1 \cdot 20$ & $2 \cdot 25$ & $1 \cdot 21$ & 1.64 \\
\hline 1 & .. & .. & .. & - & 0.72 & - & $2 \cdot 26$ & - & $1 \cdot 47$ \\
\hline 2 & .. & .. & .. & 0.31 & 0.73 & 0.08 & 0.73 & $0 \cdot 20$ & 0.73 \\
\hline 3 & $\because$ & .. & .. & $0 \cdot 15$ & - & 一 & - & 0.08 & - \\
\hline & & .. & .. & 0.42 & 0.62 & 0.32 & $1 \cdot 31$ & 0.37 & 0.96 \\
\hline
\end{tabular}


The increase affected both sexes and each age group but was most marked in girls and those aged one year.

There were four deaths from abuse in the retrospective series, giving an annual rate of 0.04 per thousand under four years. There were two deaths from abuse in the prospective series, an annual rate of 0.09 per thousand under four years, an increase of $2 \cdot 25$ times.

\section{Features of the Retrospective Series of CHILDREN}

The children were much more frequently abnormal at birth than in the population as a whole. Eight $(21 \%)$ were premature compared with $6.7 \%$ in the Perinatal Mortality Survey (Butler and Bonham, 1963). Four children $(10 \%)$ had congenital defects compared with about $3 \%$ in most surveys. Three had heart defects, one of whom was a mongol. One of these three had a squint, and the fourth had abnormally long second toes which required surgical correction. Nine $(23 \%)$ of the children were illegitimate compared with $7.6 \%$ in the local population. The mothers of eight of the children had originally requested termination of the pregnancy or sterilization, but had been refused.

Prominent clinical features of the presenting children were closely similar to those reported by Galdston (1965). They included fear of parents or other adults $(42 \%)$, withdrawal, listlessness or drowsiness $(42 \%)$, hyperactivity or repetitive motor activity $(29 \%)$, persistent crying or irritability $(45 \%)$, and marked pallor (34\%). All these figures are exclusive of severely subnormal children. Fear of adults was often extreme and sometimes associated with situations in which abuse had occurred such as toilet training, bathing, or play. Unresponsive, apathetic children sometimes showed no reaction to their injuries, and often were characterized by their parents as useless or lazy. Withdrawal, irritability, and crying or screaming apparently brought on by neglect or abuse, often precipitated further attacks which reinforced the behaviour.

INJURIES A total of 225 separate incidents consisting of one or more injuries were ascertained among the 38 children, a mean of 5.9 incidents per child with a range of 1 to 23 . The main classes of injury and numbers of children affected are shown in Table IV. As might be expected, nearly all the children had soft tissue injuries and were judged to have been emotionally affected by the assaults, but the high proportion of children severely physically damaged in several ways is outstanding. Altogether 517 separate physical injuries and
TABLE IV

TYPE OF INJURY

\begin{tabular}{|c|c|c|c|}
\hline Type of Injury & $\begin{array}{l}\text { No. at } \\
\text { Risk* }\end{array}$ & $\begin{array}{l}\text { No. } \\
\text { Affected }\end{array}$ & $\begin{array}{l}\text { Proportion } \\
\text { Affected }\end{array}$ \\
\hline Skull fracture & 38 & 12 & $31 \cdot 6$ \\
\hline $\begin{array}{l}\text { Intracranial haemorrhage } \\
\text { and other brain injury.. }\end{array}$ & 37 & 16 & $43 \cdot 2$ \\
\hline $\begin{array}{lcc}\text { Fractures } & \text { other } & \text { than } \\
\text { skull } & \ldots & \ldots\end{array}$ & 38 & 22 & $57 \cdot 9$ \\
\hline Soft tissue injuries $\quad \ldots$ & 38 & 36 & $94 \cdot 7$ \\
\hline Severe neglect reported & 36 & 18 & $47 \cdot 4$ \\
\hline $\begin{array}{l}\text { Starvation, deprivation } \\
\text { of fluids, failure to thrive } \\
\text { for non-medical reasons, } \\
\text { medically confirmed .. }\end{array}$ & 36 & 10 & $27 \cdot 8$ \\
\hline $\begin{array}{l}\text { Persistent or severe } \\
\text { emotional trauma } \quad .\end{array}$ & 28 & 25 & $89 \cdot 3$ \\
\hline
\end{tabular}

* Includes only children known to have been at risk

Some types of damage such as 'failure to thrive' and emotional trauma were not applicable to some children, as when the child was not with the relevant parent for a long enough period.

illnesses, including healed or partially healed fractures, were ascertained, a mean of 13.6 per child. This is almost certainly a considerable underestimate because healed superficial injuries which were not medically treated were missed. There were 40 instances of brain damage, speech and locomotor defects probably caused by injury, most of the affected children exhibiting more than one defect. The specific injuries and defects are enumerated, together with the numbers of children affected, in Tables V and VI. Fractures, bruising of the head, face, body, and limbs, and lacerations about the head and face were most common, but episodes of unconsciousness were also frequent. Malnutrition, dehydration, and infections associated with these insults were common. Severe and irreparable damage to the brain and central nervous system caused by fractures of the skull and bleeding into or around the brain were disturbingly frequent. The mean annual rate for skull fracture over the seven-year period of the study was 0.12 per thousand for children under four years and that for intracranial haemorrhage was $0 \cdot 16$ per thousand. Since these rates are likely to be underestimates of similar order to the overall rate for the retrospective series, it is probable that abuse contributes substantially to the total rates for these injuries in this age group.

Multiple injuries and multiple incidents are well-known features of these assaults, and it has been observed that injuries to the head and face are often experienced repeatedly by the same child (Castle and Kerr, 1972; Skinner and Castle, 1969). 
TABLE V

ALL ASCERTAINED INJURIES AND DISABILITIES OF THE 38 INDEX CHILDREN

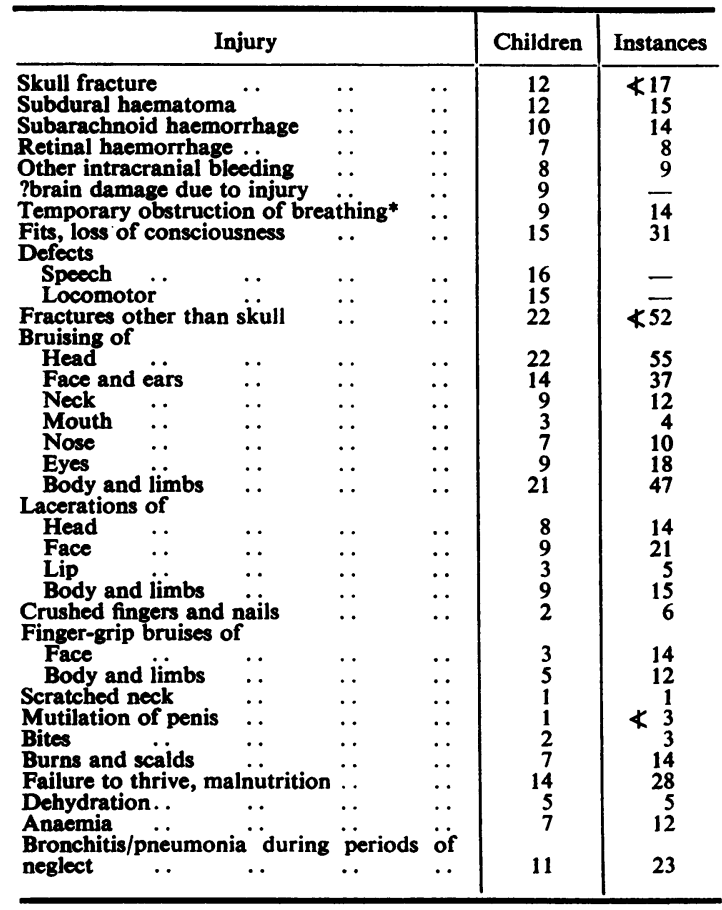

- Reports by parents, relatives, or neighbours. Includes holding head under water (5 instances), head in polythene bag ( 2 instances). hands around throat (1 instance), hands or pillow over face (6 instances).

TABLE VI

FRACTURES OF THE 38 INDEX CHILDREN

\begin{tabular}{|c|c|c|c|c|c|c|}
\hline \multicolumn{5}{|c|}{ Injury } & \multirow{2}{*}{$\begin{array}{c}\text { Children } \\
12\end{array}$} & \multirow{2}{*}{$\frac{\text { Instances }}{\$ 17}$} \\
\hline Skull & . & .. & .. & .. & & \\
\hline Femur & .. & . & . & .. & 7 & 8 \\
\hline Tibia & . & .. & .. & .. & 2 & 2 \\
\hline Fibula & .. & . & . & .. & 2 & 2 \\
\hline Clavicle & . & .. & . & .. & 2 & 2 \\
\hline Humerus & .. & .. & . & . & 3 & 3 \\
\hline Radius & . & .. & $\cdots$ & . & 3 & 3 \\
\hline Ulna & .. & .. & . & .. & 4 & 4 \\
\hline Pelvis & . & .. & . & . & 2 & 2 \\
\hline Ribs & .. & .. & .. & .. & 7 & 26 \\
\hline \multicolumn{4}{|c|}{ Three or more fractures at once } & .. & 7 & 7 \\
\hline
\end{tabular}

This was found also in some of our series of children. Although multiple fractures were common, it appears that, apart from the skull and ribs, the same fracture rarely recurs in the same child.
Duration of Severe Abuse The total periods (regardless of age at ascertainment) over which severe abuse extended varied widely. In three cases severe battering took place only in the space of one to four hours, and in two others during one to three days. Four children were severely abused during one to two weeks. The most common history was of severe abuse extending over one to 10 months (17 children), while the remaining 12 children were subjected to repeated episodes covering from one to over eight years. When lesser degrees of abuse were taken into account the distribution shifted towards the very long periods with 16 children affected from one to over eight years.

It is important to emphasize that, of the five children who were assaulted during a period of hours or days, only one escaped permanent damage. One was killed, two were rendered severely subnomal and one of these became blind and deaf as well, while the fifth became epileptic with an abnormal electro-encephalogram (EEG) and probably was made educationally subnormal.

Outcome Not all the long-term effects of the injuries will have been apparent in the younge or more recently injured children by the end of the study period in mid-1973. Nevertheless, foup $\overrightarrow{0}$ $(10 \%)$ were said to have been killed by parents. 그. two $(0 \cdot 02 / 1000 /$ annum) from brain haemorrhage after skull fracture, and two (0.02/1000/annum) from asphyxia caused by inhalation of vomit. Of those remaining alive on whom an assessment was possible, eight out of $30(27 \%)$ were intellectually impaired due to induced brain damage, 10 out of $30(33 \%)$ had fits or abnormal EEG patterns, and 17 out of $31(55 \%)$ had permanent scarring or disablement caused by their injuries. Social, educational or emotional disturbance, or probable intellectual impairment was noted in 22 out of 29 (76\%) children.

Of the 34 survivors, $14(41 \%)$ remained with the parent or parents responsible for the injuries, and only three $(9 \%)$ were with parents or relatives who had not injured them, by the end of the study. A further three had been adopted, $13(38 \%)$ were permanently or intermittently in foster homes, and $10(29 \%)$ had been in hospitals or institutions for long periods.

Structure and Features of the Retrospective SERIES OF 34 FAMILIES

MARITAL Condition In $26(76 \%)$ of the families, the married natural parents were responsible for the $\mathbb{D}$ children when the principal injuries occurred, four? 
families consisted of a natural parent and a stepparent or cohabitee, two were adoptive families, while two had unmarried mothers. In eight $(24 \%)$ families at least one of the natural parents had been divorced, compared with 0.58 expected in a sample of married and divorced persons of the same sex and age structure in north-east Wiltshire, nine (27\%) had been separated, and two had been widowed. Six $(18 \%)$ of the men were away for long periods in the armed forces or in prison. (The proportion of natural parents in the prospective series of 22 families who were divorced, separated or parted by, for instance, imprisonment or hospitalization, was $36 \%$ ). Four men and three women were in their second marriages. The mean age at marriage or cohabitation of the responsible parents was 21 years for women (ranging from 16 to 39) and 23 years for men (ranging from 16 to 37 ). Sixteen women and six men were under the age of 20 years at marriage or start of cohabitation.

OrIGIN The place of birth distribution of the parents or guardians in the $\mathbf{3 4}$ families is shown in Table VII. While the majority of parents came from England, more of the men than women 'belonged' to north-east Wiltshire.

TABLE VII

ORIGIN OF PARENTS OR GUARDIANS

\begin{tabular}{|c|c|c|c|c|c|}
\hline \multicolumn{4}{|c|}{ Birthplace } & \multirow{2}{*}{$\frac{\text { Males }}{11}$} & \multirow{2}{*}{$\frac{\text { Females }}{7}$} \\
\hline Swindon & .. & .. & . & & \\
\hline North-east & tshire & .. & .. & 2 & 2 \\
\hline London & .. & .. & . & 8 & 4 \\
\hline Rest of En & & .. & .. & 6 & 14 \\
\hline Scotland & . & .. & .. & 1 & 1 \\
\hline Northern I & nd. . & .. & .. & 1 & 1 \\
\hline Southern I & & $\cdots$ & .. & 1 & 1 \\
\hline Foreign & .. & .. & .. & 2 & 1 \\
\hline Unknown & .. & .. & .. & 2 & 3 \\
\hline Total . & . & . & .. & 34 & 34 \\
\hline
\end{tabular}

Occupation And Social Position It was difficult to construct reliable occupational histories of the fathers or male guardians. Most of them had unstable work records with frequent changes of job and periods of unemployment. Table VIII gives the best distribution which could be compiled, although its reliability is not high. Some of the unskilled labourers had occasional jobs as lorry or
TABLE VIII

OCCUPATION OF FATHERS OR MALE GUARDIANS

\begin{tabular}{|c|c|c|c|c|}
\hline \multicolumn{2}{|c|}{$1965-71$ Series } & \multicolumn{3}{|c|}{1972 - mid-73 Series } \\
\hline Unskilled labourers & .. 24 & Unskilled labou & urers & .. 13 \\
\hline Machine operators & .. & Machine operat & & . \\
\hline Railway signalman & .. & Mechanic & . & . \\
\hline Clerk .. & . & Plasterer's assist & tant & . \\
\hline Draughtsman $\quad$. & .. & Policeman & . & .. \\
\hline Electronics engineer & . & Bookbinder & .. & .. \\
\hline Armed forces $\ldots$ & . & $\begin{array}{l}\text { Armed forces } \\
\text { None (blind) }\end{array}$ & $\begin{array}{l}\cdots \\
\ldots\end{array}$ & $\begin{array}{ll}\ldots & 3 \\
. . & 1\end{array}$ \\
\hline Total .. & .. 34 & Total .. & . & . $\quad 22$ \\
\hline
\end{tabular}

van drivers, and there was a tendency for the women to accord their partners higher occupational attainments than the facts warranted. Nevertheless, at least two out of three were Social Class V families in the retrospective series and a similar proportion of the prospective series were also. Of the 33 families with fathers or father surrogates, $16(48 \%)$ of the men were unemployed at the time of the principal injuries. (The comparable figure in the prospective series was $27 \%$ ).

Place of Residence The addresses of the index children at birth and during the most severe assaults are set out in Table IX. These do not reflect the high level of residential mobility of the families, many of whom moved house abruptly, unexpectedly, and frequently. Some families appeared to try to conceal their movements, which evidently were made in response to pressures such as creditors, health or social service staff seeking access, or hostile neighbours. The types of accommodation often were of poor quality, but half the families

TABLE IX

PLACE OF RESIDENCE OF INDEX CHILDREN

\begin{tabular}{|c|c|c|c|c|}
\hline \multicolumn{3}{|c|}{ Place of Residence } & At Birth & $\begin{array}{c}\text { During Most } \\
\text { Severe Assaults }\end{array}$ \\
\hline Swindon & .. & . & 22 & 23 \\
\hline North-east & shire & .. & 4 & 8 \\
\hline London & . & .. & 3 & 2 \\
\hline Rest of Er & & . & 7 & 5 \\
\hline Foreign & .. & .. & 2 & - \\
\hline Total & .. & .. & 38 & 38 \\
\hline
\end{tabular}


were living in relatively good conditions at the time of the main assaults-such as, council houses, some privately rented properties, and owneroccupied homes (Table $\mathrm{X}$ ). It is noteworthy that two of the children were assaulted while in mother and baby homes. The proportion who shared accommodation was lower in the retrospective series $(13 \%)$ than in the prospective series $(45 \%)$.

TABLE X

ACCOMMODATION AT TIME OF MAIN ASSAULTS

\begin{tabular}{|c|c|c|}
\hline Accommodation & ${ }_{\text {Series }}^{1965-71}$ & 1972 - mid.1973 \\
\hline $\begin{array}{l}\text { Rented } \\
\text { Privately .. }\end{array}$ & 13 & 0 \\
\hline From Council & 10 & 8 \\
\hline $\begin{array}{l}\text { Shared } \\
\text { (including 'squatting'). . }\end{array}$ & 5 & 10 \\
\hline Caravan $\quad \ldots$ & 2 & 0 \\
\hline $\begin{array}{lcr}\text { Motorway } & \text { construction } \\
\text { hut } & . & . .\end{array}$ & 1 & 0 \\
\hline Own home .. & 2 & 1 \\
\hline $\begin{array}{l}\text { Local authority mother } \\
\text { and baby home }\end{array}$ & 2 & 0 \\
\hline $\begin{array}{l}\text { Army accommodation } \\
\text { (not camps) .. }\end{array}$ & 3 & 3 \\
\hline Total & 38 & 22 \\
\hline
\end{tabular}

Adults in Loco Parentis A characteristic of $\mathscr{D}$ these families was the frequent change of adults in $D$ charge of the children as spouses, cohabitees, and relatives came and went. The distribution of the $129 ?$ parents and step-parents, or cohabitees (not includ- $\overrightarrow{\bar{F}}$ ing grandparents and foster parents), responsible at various times for the presenting children and their siblings is shown in Table XI. Only $12(35 \%)$ families had but two parents. The larger families tended to have more adults involved in care of the children, $\stackrel{\mathbb{D}}{\circ}$ a mean of 4.7 in families with four children and $ळ$ 5.6 in families with five or six children.

Sibling STructure The sibling structures of $\vec{\omega}$ the 34 families are summarized in Table XII. There $\frac{}{\infty}$ was a total of 116 children in the 34 families, a mean $\stackrel{\bigcirc}{\supset}$ of over three children per family. Over half the families had four or more children, two had six, and only two were single child families. Over half the 38 severely-abused children came from families of with four or more children, and nearly three-quarters from families with three or more children. The large size of these families compared with the countro as a whole is shown in Table XIII and would be even more marked if account were taken of the youthfulness of the parents. The siblings of the presenting children were nearly as likely to be step or half sibs as they were to be full sibs. Altos gether $30(26 \%)$ of the 116 children were illegitimate and these 30 came from half the 34 families.

TABLE XI

PARENTS AND PARENT SURROGATES RESPONSIBLE FOR CHILDREN IN THE 34 FAMILIES

\begin{tabular}{|c|c|c|c|c|c|c|c|c|c|c|}
\hline \multirow{2}{*}{\multicolumn{3}{|c|}{$\begin{array}{l}\text { No. of Parents or } \\
\text { Parent Surrogates }\end{array}$}} & \multicolumn{6}{|c|}{ No. of Children in Family } & \multirow{2}{*}{$\begin{array}{c}\begin{array}{c}\text { Families } \\
\text { (total) }\end{array} \\
12\end{array}$} & \multirow{2}{*}{\begin{tabular}{|c|}
$\begin{array}{c}\text { Parents or Surrogates } \\
\text { (total) }\end{array}$ \\
24
\end{tabular}} \\
\hline & & & $\frac{1}{2 *}$ & $\frac{2}{4}$ & $\begin{array}{l}3 \\
4\end{array}$ & $\frac{4}{2}$ & 5 & $\begin{array}{l}6 \\
-\end{array}$ & & \\
\hline $3 \ldots$ & . & $\cdots$ & - & 1 & 3 & 4 & - & - & 8 & 24 \\
\hline $4 \ldots$ & . & $\cdots$ & - & 2 & - & 3 & - & - & 5 & 20 \\
\hline $7 \ldots$ & . & $\cdots$ & 一 & - & - & 1 & - & - & 1 & 7 \\
\hline $8 \ldots$ & $\cdots$ & $\cdots$ & - & - & - & - & - & - & 0 & - \\
\hline $9 \ldots$ & $\cdots$ & .. & - & - & - & 1 & - & - & 1 & 9 \\
\hline $10 \ldots$ & . & . & - & - & - & - & - & - & 0 & - \\
\hline $\begin{array}{l}\text { Total } \\
\text { surros }\end{array}$ & $\begin{array}{c}\text { ats or } \\
.\end{array}$ & .. & 4 & 19 & 17 & 61 & 17 & 11 & & 129 \\
\hline
\end{tabular}


TABLE XII

SIBLING STRUCTURE OF THE 34 FAMILIES

\begin{tabular}{|c|c|c|c|c|c|c|c|c|c|c|}
\hline \multirow{2}{*}{\multicolumn{3}{|c|}{ Children }} & \multicolumn{6}{|c|}{ No. of Children in Family } & \multirow{2}{*}{$\begin{array}{c}\text { Families } \\
\text { (total) }\end{array}$} & \multirow{2}{*}{$\underset{\text { (total) }}{\text { Children }}$} \\
\hline & & & 1 & 2 & 3 & 4 & 5 & 6 & & \\
\hline \multicolumn{3}{|c|}{ No. presenting } & & & & & & & & \\
\hline $1 .$. & .. & .. & $2 *$ & 6 & 6 & 13 & 2 & 1 & 30 & 30 \\
\hline 2.. & .. & .. & - & 1 & 1 & - & 1 & 1 & 4 & 8 \\
\hline Subtotal & .. & .. & 2 & 8 & 8 & 13 & 4 & 3 & 34 & 38 \\
\hline \multicolumn{3}{|c|}{ No. full sibs } & & & & & & & & \\
\hline 1.. & .. &.. & - & 5 & 4 & 1 & 1 & 1 & 12 & 12 \\
\hline 2.. & .. & .. & - & - & 3 & 2 & - & - & 5 & 10 \\
\hline 3.. & .. & .. & - & - & - & 5 & - & - & 5 & 15 \\
\hline $4 .$. &.. &.. & - & - & - & - & - & 1 & 1 & 4 \\
\hline Subtotal & .. & .. & - & 5 & 10 & 20 & 1 & 5 & 23 & 41 \\
\hline \multicolumn{3}{|c|}{ No. step or half sibs } & & & & & & & & \\
\hline $1 .$. & .. & .. & - & 1 & 3 & 2 & - & - & 6 & 6 \\
\hline $2 .$. & .. & .. & - & - & - & 1 & 1 & - & 2 & 4 \\
\hline 3.. &.. &.. & - & - & - & 5 & - & - & 5 & 15 \\
\hline 4.. &.. &.. & - & - & - & - & 2 & 1 & 3 & 12 \\
\hline Subtotal &.. & .. & - & 1 & 3 & 19 & 10 & 4 & 16 & 37 \\
\hline \multirow{2}{*}{\multicolumn{2}{|c|}{$\begin{array}{r}\text { Total families } \\
\text { children }\end{array}$}} & .. & 2 & 7 & 7 & 13 & 3 & 2 & 34 & \\
\hline & & .. & 2 & 14 & 21 & 52 & 15 & 12 & & 116 \\
\hline
\end{tabular}

* Cells show numbers of families

TABLE XIII

DISTRIBUTION BY FAMILY SIZE OF CHILD ABUSE FAMILIES AND OF ALL FAMILIES IN GREAT BRITAIN*

\begin{tabular}{|c|c|c|c|c|c|c|}
\hline \multicolumn{3}{|c|}{ No. of Children } & \multicolumn{2}{|c|}{$\begin{array}{l}\text { North-east Wiltshire } \\
\text { Child Abuse } \\
\text { Families }\end{array}$} & \multicolumn{2}{|c|}{$\begin{array}{l}\text { Great Britain } \\
1966^{*} \\
\text { (thousands) }\end{array}$} \\
\hline 1 & . & $\ldots$ & 2 & $(5.9)$ & 2572 & $(41 \cdot 4)$ \\
\hline 2 & .. & .. & 7 & $(20 \cdot 6)$ & 2177 & $(35 \cdot 0)$ \\
\hline 3 & . & .. & 7 & $(20 \cdot 6)$ & 914 & $(14 \cdot 7)$ \\
\hline 4 & .. & .. & 13 & $(38 \cdot 2)$ & 348 & $(5.6)$ \\
\hline \multicolumn{2}{|c|}{5 or more } & . & 5 & $(14 \cdot 7)$ & 208 & $(3 \cdot 3)$ \\
\hline \multicolumn{2}{|c|}{ Total } & . & 34 & $(100 \cdot 0)$ & 6219 & $(100 \cdot 0)$ \\
\hline
\end{tabular}

*Source: Social Trends, 1972

Percentages are given in parentheses

Features of Siblings of the Presenting Children IN THE Retrospective Series

ChILd ABUSE Of the 78 full and step or half siblings of the presenting children, $65(83 \%)$ were considered to be at risk of abuse by reason of their age, and presence in the family in the care of adults responsible for attacks on the presenting children. Of these 65 children, severe or moderate active physical abuse was ascertained in $41(63 \%)$ and suspected in a further six $(9 \%)$, although the abuse did not meet one or more of the criteria of severity, time, place, or age necessary for inclusion in the group of presenting children. Much smaller numbers of injuries were identified in the siblings than in the presenting children. There were recorded 10 fractures including one of skull, five instances of suffocation, 14 of fits or loss of consciousness caused by assault in seven children, 73 instances of bruising, 16 of lacerations, four of crushed fingers or nails, two of bites, and nine of burns. No instances of bleeding into or around the brain or retinal haemorrhages were recorded. In view of the severe damage ascertained in many of the siblings, it seems likely that injuries such as these were not looked for, particularly those which are easy to conceal, or those 
such as retinal haemorrhages which can be detected only by special examination. Others, such as fractures of the ribs, would have been discovered only on $x$ ray. Five $(8 \%)$ of the siblings were brain damaged, $12(18 \%)$ had speech defects and six $(9 \%)$ had locomotor defects, all caused by injury, other abuse, or neglect. Severe neglect (starvation or deprivation of essentials or failure to thrive for non-medical reasons) was found in $28(43 \%)$ of these children, and repeated or severe emotional trauma in the same number. Four of the siblings had been killed by a parent or guardian, two having died from suffocation and two from brain injury. Intellectual, social, educational, or emotional damage caused by abuse was judged present in 28 $(43 \%)$ of the siblings.

An even higher proportion (57\%) than of the presenting children remained with the parents or guardians responsible for the assaults. Seventeen children $(26 \%)$ were with relatives who had not injured them, two had been adopted, six were in foster homes, and four were in a hospital or institution.

The clinical features noted in the index children were reported in the siblings in the following frequencies: fear $11(17 \%)$, withdrawal $13(20 \%)$, hyperactivity $13(20 \%)$, irritability and excessive crying $22(34 \%)$, and pallor $12(18 \%)$.

OTHER Disease In addition to the four deaths from injury, five siblings had died from other causes (prematurity, inhalation of vomit after bronchitis aggravated by hypothermia, bronchopneumonia after bronchitis, mongolism and congenital defects, and neuroblastoma). The last two of these deaths occurred in the same family, there were three siblings with congenital conditions in another family (one heart disease and talipes, one heart murmur and dislocation of hips, one cyanotic heart disease), and one child in another family had a squint and a benign systolic murmur.

Beyond the immediate siblings there were more extensive histories in several families. Five families had histories of asthma and eczema in several members over two or more generations. One family had a number of members in three generations afflicted with a form of ataxia which may have had a genetic origin or have been a consequence of poor rearing. One family was reported as having 'puny' neonates over three generations. There were cases of albinoism, ovarian dysgenesis, and subnormality in another family.

Extent of Child Abuse in the Retrospective Series of Families

It was evident from the data on siblings of the index children that the stringent criteria by which they were identified erected artificial boundaries around the problem of child abuse which did not accord with reality. It appeared to be partly a matter of chance whether injury was inflicted of such severity as to meet the criteria. For instance, blows to the head or shaking might cause intracranial or retinal haemorrhage in one child but not in another of similar age. In order to obtain a fuller picture of the extent of child abuse by the parents or guardians in these families, the data on both severe and moderate physical abuse were combined and coupled with cases of neglect for both index children and siblings. Of the 116 children in these families, 15 were not at risk, either because they had died from natural causes, or were not living in the family (two children in this group had been abused by relatives while in the family but were not included in the following analyses). Of the 101 children at risk only $14(14 \%)$ were well cared for. A further six $(6 \%)$ had been subject to neglect but not active abuse. Thus in all, $81(80 \%)$ had been abused. Eight ( $8 \%$ ) had been killed, $40(40 \%)$ had been severely abused, and the remaining $33(33 \%)$ moderately abused.

An important aspect of the pattern of child abuse $\stackrel{\mathbb{D}}{\circ}$ in these families was the tendency, noted in an earlier study, for assaults to be propagated from one 0 child to the next as the family size increased (Skinner and Castle, 1969). In our series $79 \%$ of first born children were attacked, the proportion rising to $93 \%$ of second born, then falling to $70 \%$ of third born, and $88 \%$ of fourth born. A more precise calculation can be made on the basis of eldest to youngest at risk, eliminating vicarious absences which distort the birth order pattern of risk. Of eldest children at risk, $82 \%$ had been attacked. If the eldest had been assaulted, the likelihood of the second eldest being abused was $78 \%$. If the two oldest children were abused, $64 \%$ of the third oldest children were also. The proportion of fourth children abused if their three older siblings had been was $50 \%$.

\section{Characteristics of the Parents}

AbUSING BeHAVIOUR Although there was a multiplicity of parent figures at various times in most of the 34 families, it was possible to identify a man and a woman in all but one case who were responsible for the presenting children at the time of the injuries, one or both of whom were implicated in the attacks to varying degrees. The exception was a family with an unmarried mother and no father figure present at the time. The sex and ascertained degree of involvement of the parents or guardians present at the time of the assaults is shown in Table XIV. There was a significant excess 
TABLE XIV

SEX AND DEGREE OF INVOLVEMENT OF PARENTS OR GUARDIANS IN ABUSE OF PRESENTING CHILDREN

\begin{tabular}{|c|c|c|c|c|}
\hline & \multicolumn{2}{|c|}{ Men } & \multicolumn{2}{|c|}{ Women } \\
\hline Responsible & 12 & $(40 \cdot 0)$ & 27 & $(81 \cdot 8)$ \\
\hline Active complicity. . & 6 & $(20 \cdot 0)$ & 3 & $(9 \cdot 1)$ \\
\hline Not involved & 12 & $(40 \cdot 0)$ & 3 & $(9 \cdot 1)$ \\
\hline Total* .. & 30 & $(100 \cdot 0)$ & 33 & $(100 \cdot 0)$ \\
\hline
\end{tabular}

*There were four families in which no man and one in which no woman could have been responsible for the severe assaults because they were away at the time.

Percentages are given in parentheses

of females responsible or thought to have complied actively in the assaults ( $\chi^{2}$ with Yates' correction $=$ $6 \cdot 66$, df $=1, \mathrm{P}<0.01)$. There were $16(47 \%)$ families in which the woman alone was responsible for the assaults, and four (12\%) in which the man alone was responsible. In the remaining $14(41 \%)$ both partners attacked the children or one actively complied in assaults by the other (seven families).

There was a tendency for the main assaults to take place soon after marriage or the start of cohabitation, the mean age of women being 24 years and that of men 25 years. The mean time elapsing between marriage or beginning cohabitation and the start of severe child abuse was, for abusing women two years nine months, and for abusing men one year eight months. Seven women and five men severely assaulted the children within a year after legal or common law marriage. Five men and 16 women severely assaulted the children less than one year after the birth of their first child. There was evidence that lesser degrees of abuse occurred still earlier.

Characteristic behaviour patterns were noted in many of the parents or guardians. Gross neglect of the children was common, usually by deprivation of food and fluids, and also of warmth, light, treatment, or protection, or simply leaving babies or toddlers alone for several days or nights. Eighteen $(47 \%)$ of the index children were affected in this way on 49 occasions, and $37(57 \%)$ of the siblings on 68 occasions. Abandonment or leaving children in the care of unwilling relatives or strangers occurred less frequently (eight $(21 \%)$ index children in 14 episodes, and five ( $8 \%$ ) siblings in six episodes). Non-attendance at clinics for inadequate reasons and refusal of access in the home by professional people were very common $(29(76 \%)$ index children on 86 occasions, 39 (60\%) siblings on 64 occasions). It is noteworthy that this deliberately manipulative behaviour often gave rise to friction between the different professional people concerned, such as hospital service staff, social workers, and staff of the local health authority.

Pathological Histories Perhaps the most impressive feature of the parents and parent substitutes was the constellation of pathologies and of their own unsatisfactory childhoods which they exhibited (Oliver and Cox, 1973; Oliver and Dewhurst, 1969; Oliver and Taylor, 1971; Oliver et al., 1974). Table XV shows the frequency of 19 characteristics in the 67 parents or guardians responsible for the index children at the time of the principal assaults. The high rates of physical and mental abuse and neglect in their childhoods were outstanding. The proportions of illegitimacies, abandonment and fostering, special schooling, behaviour disorder, and agency support were all extremely high. The pathological behaviour and ill-health was equally striking in adulthood. Bearing in mind the youthfulness of these parents, there were gross excesses of psychiatric disturbance, physical illness and disability, and criminality. Even in the absence of controls it may be assumed that these characteristics together mark off this group of inadequate and unhealthy individuals from the general population.

To assess the importance of these characteristics in relation to the actual abuse of the index children, parents and guardians who were directly or indirectly implicated were compared with those who were not (Table XVI). The small numbers and the high proportion of cases in which data were not available made precise evaluation difficult. There were no significant differences between men and women, but taking both sexes together, where there were more than trivial numbers of cases, implicated parents or guardians were more likely to exhibit these features than those who were not. Implicated men were more likely to have each of the characteristics except subnormality than unimplicated men, although the difference reached significance only with respect to social agency support as an adult ( $\chi^{2}$ with Yates' correction $\left.=4 \cdot 43, \mathrm{df}=1, \mathrm{P}<0.05\right)$. There were no statistically significant differences among the mothers or female guardians, and with respect to neglect as a child, illegitimacy or premarital conception, history of educational subnormality or special schooling, and extensive agency support as a child and as an adult, those not implicated in the assaults were more likely to be affected than those who were. Although these results suggest that those exhibiting assaultative behaviour were not readily distinguishable from their unimplicated partners in these terms, significant 
TABLE XV FREQUENCY OF CERTAIN CHARACTERISTICS IN 67 PARENT FIGURES OF THE SEVERELY-ABUSED CHILDREN

\begin{tabular}{|c|c|c|c|c|c|c|c|c|}
\hline Characteristic & \multicolumn{2}{|c|}{ Present } & \multicolumn{2}{|c|}{ Absent } & \multicolumn{2}{|c|}{ Not Applicable } & \multicolumn{2}{|c|}{ Not known } \\
\hline $\begin{array}{l}\text { Childhood } \\
1 \text {. Severe or moderate physical abuse }\end{array}$ & $28^{*}$ & $(41 \cdot 8)$ & 17 & $(25 \cdot 4)$ & - & - & 22 & $(32 \cdot 8)$ \\
\hline neglect & 28 & $(41 \cdot 8)$ & 16 & $(23 \cdot 9)$ & - & - & 23 & $(34 \cdot 3)$ \\
\hline or prolonged mental abuse & 39 & $(58 \cdot 2)$ & 4 & $(6 \cdot 0)$ & 1 & $(1 \cdot 5)$ & 23 & $(34 \cdot 3)$ \\
\hline 4. Illegitimate or premarital conception .. & 10 & $(14 \cdot 9)$ & 47 & $(70 \cdot 2)$ & - & - & 10 & $(14 \cdot 9)$ \\
\hline 5. Abandoned, institutionalized, or fostered & 18 & $(26 \cdot 9)$ & 33 & $(49 \cdot 3)$ & - & - & 16 & $(23 \cdot 8)$ \\
\hline $\begin{array}{l}\text { 6. Prolonged (over } 1 \mathrm{mth} \text { ) separation from } \\
\text { one or both parents }\end{array}$ & 28 & $(41 \cdot 8)$ & 21 & $(31 \cdot 3)$ & - & - & 18 & $(26 \cdot 9)$ \\
\hline $\begin{array}{l}\text { 7. Educationally } \\
\text { schooling } \\
\text {.. }\end{array}$ & 11 & $(16 \cdot 4)$ & 37 & $(55 \cdot 2)$ & 6 & $(9 \cdot 0)$ & 13 & $(19 \cdot 4)$ \\
\hline 8. Conduct, learning, or emotional disorder & 33 & $(49 \cdot 2)$ & 11 & $(16 \cdot 4)$ & 6 & $(9 \cdot 0)$ & 17 & $(25 \cdot 4)$ \\
\hline $\begin{array}{l}\text { 9. Extensive agency support (Oliver and } \\
\text { Cox, 1973). }\end{array}$ & 26 & $(38 \cdot 8)$ & 14 & $(20 \cdot 9)$ & 6 & $(9 \cdot 0)$ & 21 & $(31 \cdot 3)$ \\
\hline Adulthood & & & & & & & & \\
\hline $\begin{array}{l}\text { 10. History of stealing, violence, sex offences, } \\
\text { or other criminal behaviour .. }\end{array}$ & 31 & $(46 \cdot 3)$ & 34 & $(50 \cdot 7)$ & - & - & 2 & $(3 \cdot 0)$ \\
\hline $\begin{array}{lll}\text { 11. Extensive } & \text { agency support (Oliver and } \\
\text { Cox, 1973).. } & . . & .\end{array}$ & 45 & $(67 \cdot 2)$ & 21 & $(31 \cdot 3)$ & - & - & 1 & $(1 \cdot 5)$ \\
\hline 12. Chronic physical ill-health or disability.. & 17 & $(25 \cdot 4)$ & 50 & $(74 \cdot 6)$ & - & - & - & - \\
\hline 13. Episodes of unconsciousness .. & 19 & $(28 \cdot 4)$ & 48 & $(71 \cdot 6)$ & - & - & - & - \\
\hline $\begin{array}{l}\text { 14. History of uncontrolled drug or alcohol } \\
\text { use }\end{array}$ & 8 & $(11 \cdot 9)$ & 54 & $(80 \cdot 6)$ & - & - & 5 & $(7 \cdot 5)$ \\
\hline $\begin{array}{l}\text { 15. Borderline or moderate } \\
\text { normality } \ldots\end{array}$ & 20 & $(29 \cdot 8)$ & 45 & $(67 \cdot 2)$ & - & - & 2 & $(3 \cdot 0)$ \\
\hline 16. Personality or neurotic disorder & 51 & $(76 \cdot 1)$ & 10 & $(14 \cdot 9)$ & - & - & 6 & $(9 \cdot 0)$ \\
\hline 17. History of suicidal attempts or gestures.. & 20 & $(29 \cdot 8)$ & 43 & $(64 \cdot 2)$ & - & - & 4 & $(6 \cdot 0)$ \\
\hline psychiatric treatment & 39 & $(58 \cdot 2)$ & 24 & $(35 \cdot 8)$ & - & - & 4 & $(6 \cdot 0)$ \\
\hline psychiatric inpatient treatmen $t$ & 23 & $(34 \cdot 3)$ & 38 & $(56 \cdot 7)$ & - & - & 6 & $(9 \cdot 0)$ \\
\hline
\end{tabular}

*Includes 10 cases in whom severe or moderate physical abuse was probable but evidence was not complete Percentages are given in parentheses 
TABLE XVI

PROPORTION OF PARENTS OR GUARDIANS WITH VARIOUS CHARACTERISTICS BY SEX ANDIMPLICATIONINASSAULTS

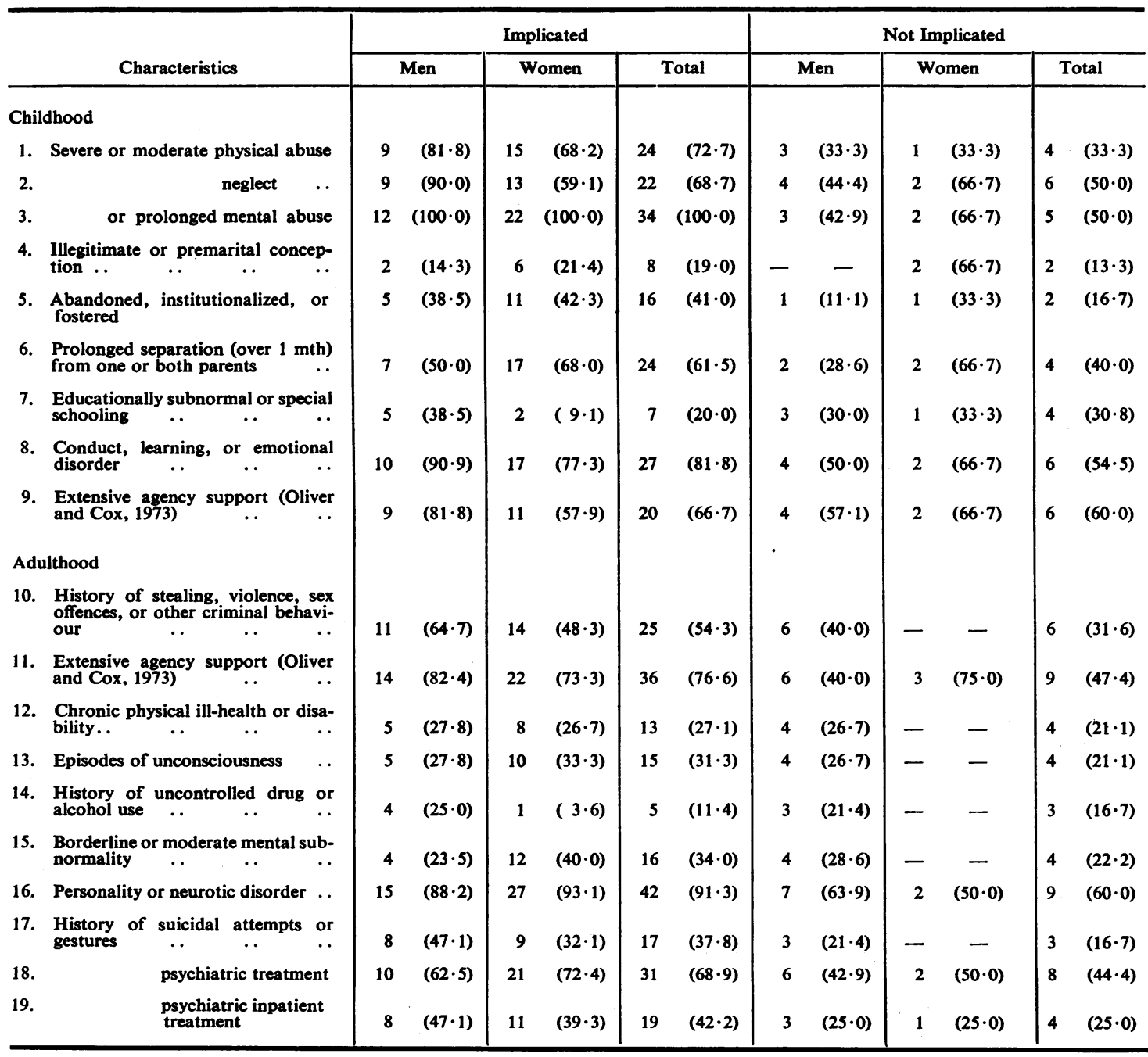


differences were obtained when the characteristics were grouped. Implicated parent figures were more likely to have been subjected to physical or mental abuse or neglect in their own childhoods (Table XVII), and they were more likely to have one or more features of an unhealthy or unsatisfactory childhood (Table XVIII).

\section{TABLE XVII}

COMPARISON OF IMPLICATED AND UNIMPLICATED PARENTS OR GUARDIANS WITH DEFINITE OR PROBABLE PHYSICAL OR MENTAL ABUSE OR NEGLECT IN CHILDHOOD

\begin{tabular}{cc|rr|rr||rr}
\hline $\begin{array}{c}\text { Abuse or } \\
\text { Neglect }\end{array}$ & \multicolumn{2}{|c|}{ Implicated } & \multicolumn{2}{|c|}{ Not Implicated } & \multicolumn{2}{|c}{ Total } \\
\hline Yes &.. & 34 & $(91 \cdot 9)$ & 7 & $(50 \cdot 0)$ & 41 & $(80 \cdot 4)$ \\
No &.. & 3 & $(8 \cdot 1)$ & 7 & $(50 \cdot 0)$ & 10 & $(19 \cdot 6)$ \\
\hline Total &.. & 37 & $(100 \cdot 0)$ & 14 & $(100 \cdot 0)$ & 51 & $(100 \cdot 0)$ \\
\hline
\end{tabular}

Exact probability $=2 \cdot 93 \%$ (two-tailed)

TABLE XVIII

COMPARISON OF IMPLICATED AND UNIMPLICATED PARENTS OR GUARDIANS WITH ONE OR MORE FEATURES OF AN UNSATISFACTORY CHILDHOOD*

\begin{tabular}{l|rr|rr|rr}
\multicolumn{1}{c|}{ Childhood } & Implicated & \multicolumn{2}{|c|}{ Not Implicated } & \multicolumn{2}{|c}{ Total } \\
\hline $\begin{array}{l}\text { Unsatis- } \\
\text { factory }\end{array}$ & 40 & $(85 \cdot 1)$ & 8 & $(50 \cdot 0)$ & 48 & $(76 \cdot 2)$ \\
Normal & 7 & $(14 \cdot 9)$ & 8 & $(50 \cdot 0)$ & 15 & $(23 \cdot 8)$ \\
\hline Total.. & 47 & $(100 \cdot 0)$ & 16 & $(100 \cdot 0)$ & 63 & $(100 \cdot 0)$ \\
\hline
\end{tabular}

Exact probability $=1 \cdot 28 \%$ (two-tailed)

*Based on items 1-9 of Table XVI

\section{Discussion}

\section{Extent of Child Abuse}

The rate of about one new case referred per thousand children under four years old per year followed intensive educative activity with medical and social welfare workers. For England and Wales as a whole this rate would entail referral of over 3000 children aged under three years each year. Although this rate was an increase of over two and a half times the ascertainment rate in the previous seven years, there were clinical indications of residual under reporting and the true rate almost certainly is higher. Although we have detailed data only on the retrospective series, it seems likely that the proportion with brain damage is similar in the prospective series. At over $40 \%$ this would mean 1200 children per year in the country as a whole.
These figures may be taken as a reasonable estimate of the extent of severe abuse in this age group using the criteria and methods of ascertainment of the study, yet they are by no means an indication of the extent of child abuse as a whole. Three principal qualifications must be taken into account. First, almost no children over three years of age were ascertained because this group appears to escape injury of such severity although it is frequently subjected to less damaging assaults. Our figures for brain damage may therefore be fairly firm. Indeed, all but two of the 38 children in the retrospective series and one of the 22 in the prospective series were under three years, so severe physical abuse as here defined and identified is virtually confined to the age group from birth to two years. In the prospective series the total annual rate for this group was about $1 \cdot 3$ per thousand. Secondly, the criteria for severe abuse were very stringent. Lesser degrees of abuse were ascertained in over half the sibs of index cases at risk in addition to the $16 \%$ of sibs who were severely abused. Families ii which the children were not known to have been injured seriously enough to meet the criteria were excluded altogether. Thirdly, nearly all the familis were in social classes IV and V and it must be questionable whether this is at least partially $\mathbb{\mathbb { Q }}$ consequence of the methods of ascertainmer $\vec{v}$ rather than a reflection of the situation. Kempe ov (1971) believes that child abuse occurs more or les5 equally in all social classes, and Ounsted (1975) hàs not experienced a preponderance of lower-class families in Oxford. It can be argued that concealment of child abuse would be more effective in the higher $\Phi$ social classes and there were indications from interview material with medical and other pro- $\frac{0}{3}$ fessionals that this was so. Higher social class parents rarely sought the help of social service agencies, confining themselves to contact with the medical profession. Nevertheless, it is unlikely that $\Phi$ abuse of the severity necessary to meet our criteria? would have escaped ascertainment to any great $\frac{5}{3}$. extent in the climate of opinion of the prospective study in 1972 and 1973 . It may well be that severity is class related.

It is difficult to make useful comparisons with other studies since definitions have been less preciseo and usually all grades of abuse, and sometimes neglect, have been included. Our total rate for 0 severe abuse is not incompatible with the results 0 from the Tunbridge Wells study group (Franklin, N 1973), but the extent of brain damage is considerably $\sigma$ higher in our study. If moderate abuse had been $<$ included our total rate also might have exceeded

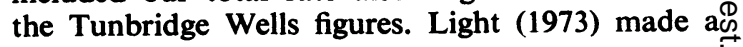


'best estimate' of three per thousand USA children under 18 years for all grades of physical abuse, and a further seven per thousand for severe neglect and sexual abuse to reach his total of $1 \%$. Kempe (1971) gave a figure of six per thousand live births for all types of abuse from severe assaults to passive rejection in the USA. The rate for severe abuse only in the present study is four per thousand live births per annum. Judging from clinical experience, application of the rates for all types of abuse given by these American authors to the United Kingdom would not be unrealistic.

The death rate in the prospective series was about $0 \cdot 1$ per thousand under four years old per year. This rate is between one-third and two-thirds of the rate for traumatic causes in the Oxford Record Linkage Study area, and represents between $2 \%$ and $2.5 \%$ of all deaths in children aged under four years.

Extrapolated to England and Wales as a whole, this death rate would account for over 300 deaths a year with a range within one standard error $(70 \%$ of samples) of 31 to 526. This contrasts with both the Tunbridge Wells study group figure of 700 per year (Franklin, 1973), and the official figure of 80 in 1972 (Peckham and Jobling, 1975). Although deaths were included only if the abuse had been prolonged sufficiently to meet the criteria so that not all infanticides or murders necessarily were counted, it seems unlikely that additional deaths of this type occurred in the north-east Wiltshire population in the 18-month-period of the prospective study. It is possible that rates may be higher in other, perhaps more heavily urbanized, parts of the country.

It is of some interest to examine possible reasons for the apparent marked under reporting of deaths from abuse in the official figures. In the retrospective series there were four deaths of index cases and four deaths of their sibs, and in the prospective series a further two index deaths were ascertained. Of these 10 deaths, inquests were held in nine, and convictions for infanticide or manslaughter obtained in three. In one other case the mother was acquitted of causing the death but convicted of cruelty to a person under 16 years. In only four of the nine cases investigated by inquest, therefore, was there considered to be evidence of assault. Coroners' verdicts in the other five were either accidental death (three cases) or open (two cases). The diagnosis in all the accidental deaths was some variant of asphyxia caused by inhalation of gastric contents. The diagnosis in one of the open verdicts was cerebral haemorrhage after fracture of the skull and in the other cerebral haemorrhage after a tentorial tear. The diagnoses in the cases associated with convictions were broncho-pneumonia and cerebral haemorrhage after fracture of skull and ribs, subdural haemorrhage after fracture of the skull, and asphyxia. In the case associated with a conviction for cruelty the diagnosis was asphyxia caused by inhalation of vomit. The tenth case, without inquest, was diagnosed after necropsy as acute bronchitis and certified by the coroner. Multiple bruising was noted in the medical notes. Two of the deaths occurred in hospital, and two other babies were dead on arrival at hospital, none of these being associated with conviction for infanticide or manslaughter.

These records suggest that where the cause of death is not overt violence there is less chance of allegation of assault leading to trial and not all cases of overt violence such as fracture of skull have this outcome. Adequate evidence clearly is difficult to obtain, but it may be useful to note that eight out of the 10 deaths occurred at ages less than one year. Death from intracranial haemorrhage associated with injury not clearly caused in situations precluding assault, or asphyxia (whether or not caused by inhalation of vomit) occurring under one year of age should be investigated most thoroughly. It would be useful if the external cause (corresponding to the $E$ code of the ICD) were noted on the death certificate wherever applicable, so that the frequency of supposed accidental causes which stretch credibility (such as being dropped, falling down stairs, etc.) may be obtained.

\section{FAmily Characteristics}

Large size, youthfulness, instability, and gross excesses of psychiatric and physical illness and disability, and criminality characterized the retrospective series of child abuse families. Clinically, families in the prospective series, although referred at the much higher rate, were similar. So marked were these features that, even in the absence of controls, it is likely that they identify a group of inadequate and unhealthy families to whom severe physical abuse is largely confined. These results are in accord with those of Smith and his colleagues in the Birmingham area (Smith and Hanson, 1974; Smith and Noble, 1973; Smith, Hanson, and Noble, 1973a; Smith, Honigsberger, and Smith, 1973b; Smith, Hanson, and Noble, 1974).

The frequency of disease in these families is suggestive of clustering of disorders and is reminiscent of Newcombe's finding (Newcombe, 1966) of greatly increased relative risk in siblings of handicapped and stillborn children for a wide range of conditions, including accidents, poisonings, and 
violence. This is clearly a subject for detailed study for which a system of linked medical records depicting the primary and integenerational family relationships would be necessary. If disease clustering in such families were confirmed and its nature and extent specified, there could be important implications for both medical knowledge and the organization of health and social care. Child abuse appears to be but a manifestation of widespread heterogeneous, and often severe medical and social pathology affecting virtually the whole family. Multiple disease and the consequent disability may become so over-whelming that the means of coping with the difficulties of living are no longer possible for the adult members. Violent impulsive aggression, shifting dependence on acquaintances and relatives, and deep ambivalence towards health, social welfare and social control agencies on which extraordinary demands are made, become a characteristic way of life. We have discussed elsewhere some implications for ascertainment, secondary and primary prevention, and organization of services (Oliver et al., 1974).

We wish to express our gratitude to our colleagues Jane Cox and Audrey Taylor, who undertook much of the data collection and analysis for this study as well as much of the clinical work, and to the very large number of doctors, social workers, probation officers, police, and charitable society workers, who gave freely of their time and made great efforts to help and collaborate with us.

Requests for reprints: Dr. J. A. Baldwin, Director, University of Oxford Unit of Clinical Epidemiology, Oxford Regional Health Authority, Old Road, Headington, Oxford OX3 7LF.

\section{REFERENCES}

Birrell, A. G. and Birrell, J. H. W. (1968). The maltreatment syndrome in children: a hospital survey. Med.J.Austr., 2, 1023.

Butler, N. R. and Bonham, D. G. (1963). Perinatal Mortality: the first report of the 1958 British Perinatal Mortality Survey. Livingstone, London.

CafFey, J. (1972). The parent-infant traumatic stress syndrome. Amer. J. Roentgenol., 114, 218.

Cameron, J. M. (1970). The battered baby. Brit. J. hosp. Med., 4, 769.

- (1972). The battered baby syndrome. Practitioner, 209, 302.

- Johnson, H. R. M., and CAMps, F. E. (1966). The battered child syndrome. Med. Sci. Law, 6, 2.

CASTLE, R. L. and KerR, A. M. (1972). A Study of Suspected Child Abuse. National Society for the Prevention of Cruelty to Children.

Cherry, B. J. and KuBY, A. M. (1971). Obstacles to the delivery of medical care to children of neglecting parents. Amer. J. publ. Hlth, 61, 568.
Clege, A. and Megson, B. (1968). Children in Distress. Penguin.

Ebrin, A. J., Gollub, M. H., Stein, A. M., and Wilson, M. G. (1969). Battered child syndrome at the Los ? Angeles County General Hospital. Amer. J. Dis. Child., 118, 660.

ELMER, F. (1960). Failure to thrive: role of the mother Pediatrics, 25, 717.

Franklin, A. W. (1973). Tunbridge Wells Study Group on Non-accidental Injury to Children. Spastics Society.

GALDSTON, R. (1965). Observations on children who have been physically abused and their parents. Amer. J. Psychiat., 122, 440.

GrantmYre, E. B. (1973). Trauma X-Wednesday's child N.S. med. Bull, 52, 29.

Griffiths, D. Ll. and Moynihan, E. J. (1963). Multiple epiphysical injuries in babies ('battered baby' syndrome) Brit. med. J., 2, 1558.

GUTHKeLCH, A. N. (1971). Infantile subdural haematoma and its relationship to whiplash injuries. Brit. med. $J$ 2,430 .

HARCoURT, B. and Hopkins, D. (1971). Ophthalming manifestations of the battered baby syndrome. Bri med. J., 3, 398.

Kempe, C. H. (1971). Paediatric implications of the battered baby syndrome. Arch. Dis. Childh., 46, 28.

KöTtGeN, U. (1967). Maltreatment of children. Mschr Kinderheilk., 115, 186.

Leonard, M. F., Rhymes, J. P., and Solnitt, A. J. (1966). Failure to thrive in infants-a family problem. Amer. J. Dis. Child., 111, 600.

LIGHT, R. J. (1973). Abused and neglected children in America: a study of alternative policies. Harv. educ. Rev., 43, 556.

Lukianowicz, N. (1971). Infanticide. Psychiat. Clin., 4, 145.

Maginnis, E., Pivchik, E., and Smith, N. (1967). A social worker looks at failure to thrive. Child Welfare, 335.

Maroteaux, P. and Fessard, C. (1969). The battered child syndrome: Silverman's syndrome. Concours med. 91, 6704.

Mushin, A. S. (1971). Ocular damage in the battered baby syndrome. Brit. med. J., 3, 402.

NeimanN, N. and Rabouille, D. (1969). Maltreated children. Rev. Prat. (Paris), 19, 3879.

Newcombe, H. B. (1966). Familial tendencies in diseases of children. Brit. J. prev. soc. Med., 20, 49.

Oliver, J. E. (1970). Huntington's chorea in Northamptonshire. Brit. J. Psychiat., 116, 241.

and Cox, J. (1973). A family kindred with ill used children: the burden on the community. Brit. J. Psychiat., 123, 81. 
- - Taylor, A., and Baldwin, J. A. (1974). Severely ill-treated young children in north-east Wiltshire. Oxford University, Unit of Clinical Epidemiology. Research Report No. 4.

— and Dewhurst, K. E. (1969). Six generations of ill-used children in a Huntington's pedigree. Postgrad. med. J., 45, 757.

- and TAYLOR, A. (1971) Five generations of illtreated children in one family pedigree. Brit. $J$. Psychiat., 119, 473.

O'Neill, J. A., Meacham, W. F., Griffin, D. P., and SAWYERS, J. L. (1973). Patterns of injury in the battered child syndrome. J. Trauma, 13, 332.

OUNSTED, C. (1975). Personal communication.

Pavenstedt, E. and Bernard, V. W. (1971). Crises of Family Disorganization. Behavioral Publications, New York.

Peckham, C. S. and Jobling, M. (1975). Deaths from non-accidental injuries in childhood. Brit. med. J., 2, 686.

Reeb, K. G., Melli, M. S., Wald, M., and Wesenberg, R. (1972). A conference on child abuse. Wis. med. J. 71, 226.

RODENBERG, M. (1971). Child murder by depressed parents. Canad. psychiat. Ass. J., 16, 41.

Scotr, P. D. (1973a). Fatal battered baby cases. Med. Sci. Law, 13, 197.

(1973b). Parents who kill their children. Med. Sci. Law, 13, 120.

Silverman, F. C. (1968). Radiologic aspects of the battered child syndrome. In The Battered Child, edited by R. E. Helfer and C. H. Kempe. University of Chicago Press.
Sims, B. G., Grant, J. H., and Cameron, J. M. (1973). Bite-marks in the battered baby syndrome. Med. Sci. Law, 13, 207

Skinner, A. E. and Castle, R. L. (1969). 78 Battered Children: a Retrospective Study. National Society for the Prevention of Cruelty to Children.

Smith, S. M. and Hanson, R. (1972). Failure to thrive and anorexia nervosa. Postgrad. med. J., 48, 382.

and

(1974). 134 battered children: a medical and psychological study. Brit. med. J., 3, 666 .

$\longrightarrow$, $\longrightarrow$ and Noble, S. (1973a). Parents of battered babies: a controlled study. Brit. med. J., 4, 388.

- - - and - (1974). Social aspects of the battered baby syndrome. Brit. J. Psychiat., 125, 568.

- Honigsberger, L., and SMITH, C.A. (1973b). EEG and personality factors in baby batterers. Brit. med. J., 2, 20.

and NoBLE, S. (1973). Battered children and their parents. New Soc., 26, 393.

Straus, P. and Wolf, A. (1970). A topical question: maltreated children. Psychiat. Enf., 12, 577.

TRUBE-BeCKER, E. (1971). Autopsy of children who have died suddenly. Med. Klin., 66, 58.

Weston, J. T. (1968). The pathology of child abuse. In The Battered Child, edited by R. E. Helfer and C. H. Kempe. University of Chicago Press.

Young, L. (1964). Wednesday's Children. McGraw-Hill, New York. 